\title{
A reunião cristã como sacramento do desígnio divino de salvação: teologia da assembleia litúrgica
}

\author{
Orientador: Luiz Fernando Ribeiro Santana \\ Mestrando: Gustavo Correa Cola \\ Área de Concentração: Teologia Sistemático-Pastoral \\ Linha de Pesquisa: Fé e Cultura
}

Pessoas reunidas sob uma convicção religiosa comum, para o exercício de alguma atividade cúltica, é fato recorrente nas mais diversas tradições religiosas. Para o cristianismo, entretanto, a reunião dos cristãos alcança um significado de todo particular e reveste-se de uma responsabilidade ímpar. Ela é sacramento - sinal evocativo, mas, ao mesmo tempo, experiência daquilo que é evocado - da própria salvação. Sua realidade está tão entranhada na trama do acontecimento salvífico, que não lhe cabe ser considerada à parte, nem é possível conhecê-la verdadeiramente por uma razão fechada às possibilidades da fé.

Esta dissertação propõe-se, então, a perseguir e desenvolver as indicações que apontam para uma "teologia da assembleia litúrgica", tendo em vista o lugar que, desde o Concílio Vaticano II, vem sendo reservado à realidade assembleal. A impostação da pesquisa é histórico-salvífica e sacramental: reunindo elementos de teologia bíblica e de "eclesiologia litúrgica", conectados por incursões no quadro histórico, nosso trabalho apresenta a assembleia como lugar mistérico onde se revela e consuma o desígnio divino de salvação.

Ao celebrar o memorial da Páscoa de Cristo e os outros sinais irradiadores da graça do mistério pascal, a assembleia manifesta e ratifica sua condição sacramental e sacerdotal, ministerial e participativa, contingente e teologal, histórica e escatológica. Responde, finalmente, àquele chamado trinitário soprado na criação, verbalizado no Sinai e encarnado no Cristo.

Palavras-chave: Teologia litúrgica; assembleia; povo de Deus. 